\title{
Microwave Synthesis, Spectral, Thermal and Electrical Properties of Some Metal Complexes Involving 5- Bromosalicylaldehyde
}

\author{
RAJENDRA K. JAIN, A.P. MISHRA*, D.K. MISHRA, AND S.K. GUPTA \\ Synthetic Inorganic \& Coordination Chemistry Laboratories \\ Department of Chemistry, Dr. H.S. Gour Central University, Sagar (M.P.)-470 003, India \\ apm19@rediffmail.com \\ rajendrajain85@rediffmail.com
}

Received 19 November 2011; Accepted 15 January 2012

\begin{abstract}
Microwave-assisted synthesis is a branch of green chemistry. The salient features of microwave approach are shorter reaction times, simple reaction conditions and enhancements in yields. Some new Schiff base complexes of $\mathrm{Cr}(\mathrm{III}), \mathrm{Co}(\mathrm{II}), \mathrm{Ni}(\mathrm{II})$ and $\mathrm{Cu}(\mathrm{II})$ derived from 5bromosalicylaldehyde with 4-nitro-1,2-phenylenediamine $\left(\mathrm{H}_{2} \mathrm{~L}^{1}\right)$ have been synthesized by conventional as well as microwave methods. These compounds have been characterized by elemental analysis, FT-IR, FAB-mass, molar conductance, electronic spectra, ESR, magnetic susceptibility and thermal analysis. The complexes exhibit coordination number 4 or 6 . The complexes are coloured and stable in air. Analytical data revealed that all the complexes exhibited 1:1 (metal: ligand) ratio. FAB-mass and thermal data show degradation pattern of the complexes. The thermal behavior of metal complexes shows that the hydrated complexes loses water molecules of hydration in the first step; followed by decomposition of ligand molecules in the subsequent steps. The solid state electrical conductivity of the metal complexes has also been measured. Solid state electrical conductivity studies reflect semiconducting nature of the complexes.
\end{abstract}

Keywords: Microwave method, 4-Nitro-1,2-Phenylenediamine, Electrical conductivity.

\section{Introduction}

Multidentate Schiff base metal complexes have a strong role in material science, bioinorganic chemistry and redox enzyme systems and may provide the basis of models for biological systems. On the other hand, the uses of these compounds in various catalytic reactions like carbonylation, hydroformylation, oxidation, reduction and epoxidation. Schiff base metal complexes of either salen or salophen type ligands with transition metal ions 
have been attracting increasing attention because of their importance in different fields, such as catalysis and material chemistry ${ }^{1-5}$.

Microwave-assisted synthesis is a branch of green chemistry. The application of microwaveassisted synthesis in organic, organometallic and coordination chemistry continues to develop at an astonishing pace. Microwave irradiated reactions under solvent free or less solvent conditions are attractive offering reduced pollution, low cost and offer high yields together with simplicity in processing and handling ${ }^{6-10}$.

\section{Experimental}

All the used chemicals and solvents were of Anal R grade. All the reagents used for the preparation of the Schiff bases were obtained from Sigma Aldrich. Elemental analyses were performed on an Elemental Vario EL III Carlo Erba 1108 analyzer. FAB-mass spectra were recorded on a JEOL SX 102/DA 6000 Mass Spectrometer. Electronic spectra (in $\mathrm{MeOH}$ ) were recorded on Perkin Elmer Lambda-2B-spectrophotometer. Molar conductance measurements were conducted using $10^{-3} \mathrm{M}$ solutions of the complexes in methanol on Elico-CM 82 Conductivity Bridge at room temperature. FT-IR spectra were recorded in $\mathrm{KBr}$ pellet on a Perkin Elmer RX1 spectrophotometer in wave number region $4000-400 \mathrm{~cm}^{-1}$. Xband EPR spectra were recorded on a Varian E-112 spectrometer at room temperature. Thermogravimetric analysis was carried out under atmospheric condition with a heating rate $10^{\circ} \mathrm{C} \mathrm{min}^{-1}$ on TGA Q500 universal V4.5A TA instrument. The solid state electrical conductivity has been measured by impedance spectroscopic method using HIOKI 3532-50 LCR Hitester at fixed frequency $1 \mathrm{KHz}$ in the temperature range of 298-413 K. Microwave assisted synthesis were carried out in open glass vessel on a modified microwave oven model $2001 \mathrm{ETB}$ with rotating tray and a power source $230 \mathrm{~V}$, microwave energy output $800 \mathrm{~W}$ and microwave frequency $2450 \mathrm{MHz}$. A thermocouple device was used to monitor the temperature inside the vessel of the microwave. The microwave reactions were performed using on/off cycling to control the temperature.

Conventional method for the Synthesis of Schiff base

$\mathrm{H}_{2} \mathrm{~L}^{1} \quad$ Schiff base was synthesized by the condensation of $2: 1$ ratio of 5bromosalicylaldehyde $(0.402 \mathrm{~g}, 20 \mathrm{mmol})$ with 4-nitrophenylene-1, 2-diamine $(0.153 \mathrm{G}, 10$ $\mathrm{mmol})$ dissolved in methanol. The resulting reaction mixture was refluxed for $6 \mathrm{~h}$ and then allowed to cool overnight. The coloured solid precipitate of Schiff base obtained was filtered, washed with cold ethanol and finally recrystallized from ethanol and ether in air at room temperature and stored in a $\mathrm{CaCl}_{2}$ desiccator. The purity of synthesized compounds was checked by TLC using silica gel G (m. p.: $282^{\circ} \mathrm{C}$; yield: $73 \%$ ).

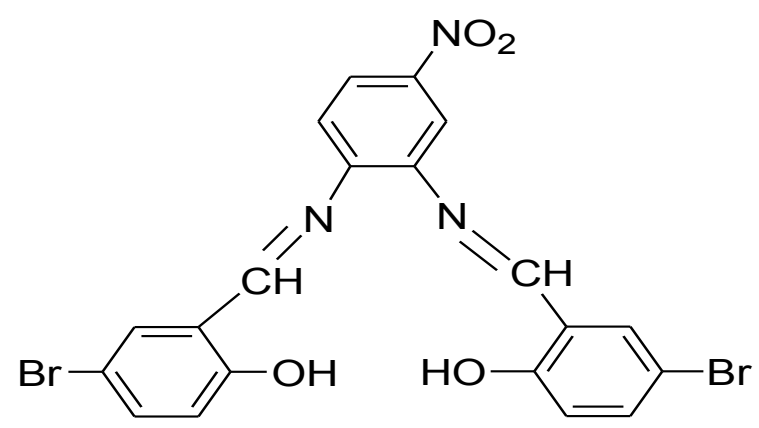

Figure 1. bis (5-bramosalicylidene)-4-nitrophenylene-1,2-diamine $\left(\mathrm{H}_{2} \mathrm{~L}^{1}\right)$. 


\section{Microwave method for the Synthesis of Schiff base}

The equimolar (2:1) ratio of 5-bromosalicylaldehyde with 4-nitrophenylene-1, 2-diamine was mixed thoroughly in a grinder. The reaction mixture was then irradiated by the microwave oven by taking $3-4 \mathrm{~mL}$ of dry ethanol as a solvent. The reaction was completed in a short time (5-6 min) with higher yields. The resulting product was then recrystallized with ethanol, finally dried under reduced pressure over anhydrous $\mathrm{CaCl}_{2}$ in a desiccator. The progress of the reaction, purity of the product was monitored by TLC using silica gel $\mathrm{G}$ (yield: 91\%).

Conventional method for the Synthesis of metal complexes

The metal complexes were prepared by the mixing of $(50 \mathrm{~mL})$ methanolic solution of $\mathrm{CrCl}_{3} \cdot 6 \mathrm{H}_{2} \mathrm{O}, \mathrm{CoCl}_{2} \cdot 6 \mathrm{H}_{2} \mathrm{O}, \mathrm{NiCl}_{2} \cdot 6 \mathrm{H}_{2} \mathrm{O}$ and $\mathrm{CuCl}_{2} \cdot 2 \mathrm{H}_{2} \mathrm{O}$ with the $(50 \mathrm{~mL})$ methanolic solution of Schiff bases $\left(\mathrm{H}_{2} \mathrm{~L}^{1}\right)$ in 1:1(metal:ligand) ratio. The resulting mixture was refluxed on water bath for 7-10 h. A coloured product appeared on standing and cooling the above solution. The precipitated complex was, filtered washed with ether and recrystallized with ethanol several times and dried under the reduced pressure over anhydrous $\mathrm{CaCl}_{2}$ in desiccator. It was further dried in an electric oven at $50-70^{\circ} \mathrm{C}$ (yield: $62-68 \%$ ).

Microwave method for the Synthesis of metal complexes

The ligand and the metal salts were mixed in 1:1 (metal:ligand) ratio in a grinder. The reaction mixture was then irradiated by the microwave oven by taking $3-4 \mathrm{~mL}$ of dry ethanol as a solvent. The reaction was completed in a short time (6-9 min) with higher yields. The resulting product was then recrystallized with ethanol and ether and finally dried under reduced pressure over anhydrous $\mathrm{CaCl}_{2}$ in a desiccator. The progress of the reaction and purity of the product was monitored by TLC using silica gel G (yield: 79-85\%).

\section{Results and Discussion}

As a result of microwave-assisted synthesis, it was observed that the reaction was completed in a short time with higher yields compared to the conventional method. In the microwave method homogeneity of reaction mixture was increased by the rotating of reaction platform tray. The confirming of the results was also checked by the repeating of the synthesis process.

All the metal complexes are coloured, solid and stable towards air and moisture at room temperature. Analytical data of the compounds and together with their proposed molecular formula are given in Table 1. All the metal chelates have 1:1 (metal:ligand) stoichiometry. The observed molar conductances of the complexes in methanol $\left(10^{-3} \mathrm{M}\right)$ at room temperature are consistent with the non-electrolytic nature of the complexes.

\section{FAB-mass spectrum}

The FAB-mass spectra suggested that all the complexes have a monomeric nature. These complexes show molecular ion peaks in good agreement with the empirical formula suggested by elemental analyses.

The FAB-mass of the $\left[\mathrm{Cu}\left(\mathrm{H}_{2} \mathrm{~L}^{1}\right)\right] 2 \mathrm{H}_{2} \mathrm{O}$ complex exhibited the molecular ion $\left(\mathrm{M}^{+}\right)$peak at $m / z=618$ suggesting the monomeric nature of the complex. The other important peaks of appreciable intensity have been observed at $\mathrm{m} / \mathrm{z}$ values, obs. (calcd.) - 587(581), 423(421), 374(375), 226(225) and 124(123) suggesting the ion species after the successive fragmentation of different groups. The intensities of these peaks give the idea of the stabilities of the fragments. The $\mathrm{m} / \mathrm{z}$ value 618 corresponds to nearest composition $\left[\mathrm{Cu}\left(\mathrm{H}_{2} \mathrm{~L} 2\right)\right] 2 \mathrm{H}_{2} \mathrm{O}$ and 124 to $\mathrm{Cu}$ metal with chelated $\mathrm{N}, \mathrm{O}$ ligand moiety ${ }^{11,12}$. 
Table 1. The comparative results of conventional and microwave methods, analytical and physical data of the compounds

\begin{tabular}{|c|c|c|c|c|c|c|c|c|c|c|}
\hline \multirow[t]{2}{*}{$\begin{array}{l}\text { Compounds } \\
\text { Colour }\end{array}$} & \multicolumn{2}{|c|}{$\begin{array}{l}\text { Reaction } \\
\text { period }\end{array}$} & \multicolumn{2}{|c|}{ Yield (\%) } & \multicolumn{4}{|c|}{ Elemental analysis, found (calcd.) \% } & \multirow[t]{2}{*}{$\begin{array}{l}\mu_{\text {eff }} \\
\text { B.M. }\end{array}$} & \multirow[t]{2}{*}{$* \Lambda_{m}$} \\
\hline & $\begin{array}{l}\text { CM } \\
\text { (h.) }\end{array}$ & $\begin{array}{l}\text { MM } \\
\text { (min.) }\end{array}$ & $\mathrm{CM}$ & MM & $\bar{C}$ & $\mathrm{H}$ & $\overline{\mathrm{N}}$ & Metal & & \\
\hline $\begin{array}{l}\mathrm{H}_{2} \mathrm{~L}^{1} \\
\left(\mathrm{C}_{20} \mathrm{H}_{13} \mathrm{~N}_{3} \mathrm{O}_{4} \mathrm{Br}_{2}\right) \\
\text { Orange }\end{array}$ & 6.0 & 5.5 & 73 & 91 & $\begin{array}{l}46.25 \\
(46.27)\end{array}$ & $\begin{array}{l}2.50 \\
(2.52)\end{array}$ & $\begin{array}{l}17.32 \\
(18.09)\end{array}$ & - & - & - \\
\hline $\begin{array}{l}{[\mathrm{Cr}(} \\
\left.\left.\mathrm{H}_{2} \mathrm{~L}^{1}\right)\left(\mathrm{H}_{2} \mathrm{O}\right) \mathrm{Cl}\right] \\
\text { Dark brown }\end{array}$ & 9.8 & 9.0 & 62 & 79 & $\begin{array}{l}38.49 \\
(38.58)\end{array}$ & $\begin{array}{l}2.05 \\
(2.10)\end{array}$ & $\begin{array}{l}6.69 \\
(6.75)\end{array}$ & $\begin{array}{l}8.31 \\
(8.35)\end{array}$ & 3.81 & 18.9 \\
\hline $\begin{array}{l}{[\mathrm{Co}(} \\
\left.\left.\mathrm{H}_{2} \mathrm{~L}^{1}\right)\left(\mathrm{H}_{2} \mathrm{O}\right)_{2}\right] \\
\text { Red }\end{array}$ & 8.5 & 8.2 & 64 & 84 & $\begin{array}{l}39.22 \\
(39.24)\end{array}$ & $\begin{array}{l}2.44 \\
(2.47)\end{array}$ & $\begin{array}{l}6.84 \\
(6.87)\end{array}$ & $\begin{array}{l}9.60 \\
(9.63)\end{array}$ & 5.01 & 9.6 \\
\hline $\begin{array}{l}{\left[\mathrm{Ni}\left(\mathrm{H}_{2} \mathrm{~L}^{\mathrm{I}}\right)\right] \cdot 2 \mathrm{H}_{2} \mathrm{O}} \\
\text { Radish brown }\end{array}$ & 6.9 & 7.8 & 68 & 80 & $\begin{array}{l}39.21 \\
(39.26)\end{array}$ & $\begin{array}{l}2.45 \\
(2.47)\end{array}$ & $\begin{array}{l}6.81 \\
(6.87)\end{array}$ & $\begin{array}{l}9.56 \\
(9.59)\end{array}$ & Dia. & 15.6 \\
\hline $\begin{array}{l}{[\mathrm{Cu}(} \\
\left.\left.\mathrm{H}_{2} \mathrm{~L}^{1}\right)\right] \cdot 2 \mathrm{H}_{2} \mathrm{O} \\
\text { Greenish brown }\end{array}$ & 7.2 & 6.2 & 66 & 85 & $\begin{array}{l}38.91 \\
(38.95)\end{array}$ & $\begin{array}{l}2.40 \\
(2.45)\end{array}$ & $\begin{array}{l}6.79 \\
(6.81)\end{array}$ & $\begin{array}{l}10.28 \\
(10.30)\end{array}$ & 1.85 & 13.1 \\
\hline
\end{tabular}

$\mathrm{CM}=$ Conventional Method; $\mathrm{MM}=$ Microwave Method ${ }^{*} \boldsymbol{\Lambda}_{\mathrm{M}}=\mathrm{Ohm}^{-1} \mathrm{~cm}^{2} \mathrm{~mol}^{-1}$

\section{IR spectra}

The IR spectra of the complexes were compared with those of the free ligand in order to determine the involvement of coordination sites in chelation. Characteristic peaks in the spectra of the ligand and complexes were considered and compared.

IR spectrum of the $\mathrm{H}_{2} \mathrm{~L}^{1}$ ligand exhibit the most characteristic bands at $3398 \mathrm{~cm}^{-1} v(\mathrm{O}-\mathrm{H})$, $1616 \mathrm{~cm}^{-1} v(\mathrm{C}=\mathrm{N}$, azomethine $)$ and $1270 \mathrm{~cm}^{-1} v(\mathrm{C}-\mathrm{O})$. All the metal complexes show a broad band at $\left(3375-3418 \mathrm{~cm}^{-1}\right)$ which may be due to $v_{\text {str }}(\mathrm{OH})$. A medium intensity band at 796 and $811 \mathrm{~cm}^{-1}$ suggested the presence of coordinated water in $\mathrm{Cr}$ (III) and $\mathrm{Co}$ (II) complexes, respectively. The band $1616 \mathrm{~cm}^{-1}$ due to the azomethine group of the Schiff base has shifted to lower frequency $\left(16-12 \mathrm{~cm}^{-1}\right)$ after complexation, indicating the bonding of nitrogen of the azomethine group to the metal ion. The phenolic $\mathrm{C}-\mathrm{O}$ stretching vibration that appeared at $1270 \mathrm{~cm}^{-1}$ in Schiff base shift towards higher frequencies $\left(12-26 \mathrm{~cm}^{-1}\right)$ in the complexes. This shift confirms the participation of oxygen in the C-O-M bond. The new 
bands at $542-557 \mathrm{~cm}^{-1}$ and $488-502 \mathrm{~cm}^{-1}$ have been assigned to $v(\mathrm{M}-\mathrm{O})$ and $v(\mathrm{M}-\mathrm{N})$ modes, respectively $^{13-17}$.

The IR data of both the Schiff base and its metal complexes show that the Schiff base $\mathrm{H}_{2} \mathrm{~L}^{1}$ is bonded to the metal ions in a tetradentate manner with ONNO donor sites of azomethine$\mathrm{N}$ and phenolic-O.

\section{Electronic spectra and magnetic moment}

The nature of the ligand field around the metal ion has been deduced from the electronic spectra. The electronic absorption spectra of the complexes were recorded at room temperature using methanol as solvent.

The $\mathrm{Cr}(\mathrm{III})-\mathrm{H}_{2} \mathrm{~L}^{1}$ complex shows electronic spectral bands at $17228 \mathrm{~cm}^{-1}$ and $23643 \mathrm{~cm}^{-1}$ these are tentatively assigned to ${ }^{4} \mathrm{~A}_{2 \mathrm{~g}} \rightarrow{ }^{4} \mathrm{~T}_{2 \mathrm{~g}}(\mathrm{~F})\left(\mathrm{v}_{1}\right)$ and ${ }^{4} \mathrm{~A}_{2 \mathrm{~g}} \rightarrow{ }^{4} \mathrm{~T}_{1}(\mathrm{~F}) \quad\left(v_{2}\right)$ transitions, respectively. The magnetic moment value is $3.81 \mathrm{~B}$.M. Thus the octahedral geometry has been suggested for this $\mathrm{Cr}(\mathrm{III})$ complex. The values of $10 \mathrm{Dq}, \mathrm{B}, \beta, \beta \%$ and LFSE are 17228 $\mathrm{cm}^{-1} 627.68 \mathrm{~cm}^{-1}, 0.609,39.09 \%, 246.99 \mathrm{kJmol}^{-1}$ respectively. The electronic spectrum of $\mathrm{Co}$ (II) complex of $\mathrm{H}_{2} \mathrm{~L}^{1}$ shows two bands at $14942 \mathrm{~cm}^{-1}$ and $19213 \mathrm{~cm}^{-1}$ these are tentatively assigned to ${ }^{4} \mathrm{~T}_{1 \mathrm{~g}} \rightarrow{ }^{4} \mathrm{~A}_{2 \mathrm{~g}}(\mathrm{~F})\left(\mathrm{v}_{2}\right)$ and ${ }^{4} \mathrm{~T}_{1 \mathrm{~g}} \rightarrow{ }^{4} \mathrm{~T}_{1 \mathrm{~g}}(\mathrm{P})\left(v_{3}\right)$ transitions, respectively. The value of magnetic moment is 5.01 B.M. Thus the octahedral geometry has been suggested for this complex. The values of $10 \mathrm{Dq}, \mathrm{B}, \beta, \beta \%$ and LFSE are $8416 \mathrm{~cm}^{-1}, 971.80 \mathrm{~cm}^{-1}, 0.868$, $13.24 \%$ and $80.44 \mathrm{~kJ} \mathrm{~mol}^{-1}$ respectively. The electronic spectrum of the $\mathrm{Ni}(\mathrm{II})-\mathrm{H}_{2} \mathrm{~L}^{1}$ complex exhibits two bands at $12268 \mathrm{~cm}^{-1}$ and $21612 \mathrm{~cm}^{-1}$ assignable to ${ }^{1} \mathrm{~A}_{1 \mathrm{~g}} \rightarrow{ }^{1} \mathrm{E}_{\mathrm{g}}\left(v_{1}\right)$ and ${ }^{1} \mathrm{~A}_{1 \mathrm{~g}} \rightarrow{ }^{1} \mathrm{~B}_{2 \mathrm{~g}}\left(v_{2}\right)$ transitions, respectively. It is a diamagnetic complex, therefore square planar geometry has been suggested for $\mathrm{Ni}(\mathrm{II})$ complex. The electronic spectrum of the $\mathrm{Cu}(\mathrm{II})-\mathrm{H}_{2} \mathrm{~L}^{1}$ complex shows show two bands at $14280 \mathrm{~cm}^{-1}$ and $18622 \mathrm{~cm}^{-1}$ assignable to ${ }^{2} \mathrm{~B}_{1 \mathrm{~g}} \rightarrow{ }^{2} \mathrm{~B}_{2 \mathrm{~g}}$ and ${ }^{2} \mathrm{~B}_{1 \mathrm{~g}} \rightarrow{ }^{2} \mathrm{E}_{\mathrm{g}}$ transitions, respectively. The value of magnetic moment for this complex is 1.85 B.M.; thus the square planar geometry has been suggested for $\mathrm{Cu}$ (II) complex ${ }^{18-21}$.

\section{ESR spectra}

The ESR spectra of $\mathrm{Cu}(\mathrm{II})$ provide information about the extent of the delocalization of unpaired electron. The X-band ESR spectra of $\mathrm{Cu}(\mathrm{II})$ complexes were recorded in the solid

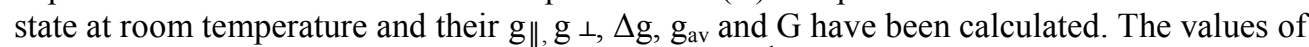

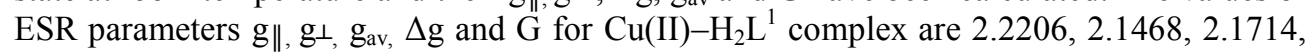
.0738 and 1.5107 respectively.

ESR spectra of the complexes revealed two $g$ values $\left(g_{\|}\right.$and $\left.g_{\perp}\right)$. Since the $g_{\|}$and $g_{\perp}$ values are closer to 2 and $\mathrm{g}_{\|}>\mathrm{g}_{\perp}$ suggesting a tetragonal distortion around the $\mathrm{Cu}$ (II) ion corresponding to elongation the fourfold symmetry Z-axis. The trend $g_{\|}>g_{\perp}>g_{e}(2.0023)$ shows that the unpaired electron is localized in $\mathrm{d}_{\mathrm{X}}^{2}-\mathrm{y}^{2}$ orbital in the ground state of $\mathrm{Cu}$ (II) and spectra are characteristic of axial symmetry. The $\mathrm{g}_{\|}>2.3$ is characteristic of an ionic environment and $\mathrm{g}_{\|}<2.3$ indicates a covalent environment in metal ligand bonding. The $\mathrm{g}_{\|}$ values for the complexes are less than 2.3 indicating, the environment is covalent.

The exchange coupling interaction between two $\mathrm{Cu}(\mathrm{II})$ ions is explained by Hathaway expression $\mathrm{G}=\left(\mathrm{g}_{\|}-2.0023\right) /\left(\mathrm{g}_{\perp}-2.0023\right)$. When the value $\mathrm{G}<4.0$ a considerable exchange coupling is present in solid complex. The value of $G$ are less than four $(G<4.0)$, also suggests the strong or medium field nature of the ligands ${ }^{22,23}$.

\section{Thermal analyses}

The thermal behavior of metal complexes shows that the hydrated complexes lose molecules of hydration first; followed by decomposition of ligand molecules in the subsequent steps.

The thermogram of the $\mathrm{Ni}(\mathrm{II})-\mathrm{H}_{2} \mathrm{~L}^{1}$ complex shows that the complex starts decomposing at $80^{\circ} \mathrm{C}$. Elimination of lattice water molecules has been observed on increasing the temperature up to $120^{\circ} \mathrm{C}$ (Remaining Wt. \%, obs. /calcd., 94.60/94.12). The complex does 
not show any loss in weight between $120-290^{\circ} \mathrm{C}$. After $290^{\circ} \mathrm{C}$, a loss in weight has been observed in general up to $465^{\circ} \mathrm{C}$ corresponding to the loss of partially decomposed ligand part from the complex (Remaining Wt.\%, obs./calcd., 42.42/92.22). Above $460^{\circ} \mathrm{C}$, an inflection occurs in the curve and loss in weight goes up to $630^{\circ} \mathrm{C}$. This indicates the elimination of the remaining thermally degradable part of the complexes. After $630^{\circ} \mathrm{C}$ a horizontal curve has been observed which corresponds to a mixture of metal oxide as an ultimate pyrolysis product (Remaining Wt.\%, obs./calcd., 24.7/19.94) ${ }^{24,25}$.

The thermal analysis evaluating the thermal stability of the metal complexes, this study also helped to characterize the metal complexes.

\section{Electrical conductivity}

The temperature dependence of the solid state conductivity $(\sigma)$ of the compounds in their compressed pellet form have been measured at fixed frequency $1 \mathrm{KHz}$ in the temperature range $297-413 \mathrm{~K}$. the values of the solid state electrical conductivity of the Schiff base and its complexes increases with increasing temperature and decreases upon cooling over the studies temperature range indicating their semiconducting behavior. The general behavior of electrical conductivity follows the Arrehenius equation:

$$
\sigma=\sigma_{\mathrm{o}} \exp (-\mathrm{Ea} / \mathrm{KT})
$$

where $\mathrm{Ea}$ is the thermal activation energy of conduction, $\sigma_{\mathrm{o}}$ is the conductivity constant and $\mathrm{K}$ is the Boltzman constant. The lots of $\sigma$ vs $1000 / \mathrm{T}$ for all the compounds are found to be linear over a studies temperature range. The room temperature electrical conductivity of all the compounds lies in the range $3.16 \times 10^{-7}-1.09 \times 10^{-9} \mathrm{ohm}^{-1} \mathrm{~cm}^{-1}$. These values show their semi-conducting nature. The electrical conductivity at room temperature decreases in order $\mathrm{H}_{2} \mathrm{~L}^{1}>\mathrm{Cr}>\mathrm{Co}>\mathrm{Cu}>\mathrm{Ni}$. Repeated measurements showed a similar conductivity pattern for all the complexes confirming the temperature dependence conductivity of the compounds ${ }^{26,27 .}$

\section{Conclusion}

In the present research studies, our successful efforts are synthesize some newly materials. These synthesized compounds Characterize by various physicochemical and spectral analyses. The synthesized $\mathrm{H}_{2} \mathrm{~L}^{1}$ ligand coordinates to the metal ions in a tetradentate manner, with ONNO donor sites of phenolic-O and azomethine-N. Thermogravimetric studied of the complexes also helped to characterize the complexes. Electrical conductivity data suggest that all the complexes fall in the semiconducting range.

\section{Acknowledgement}

We are thankful to I.I.T. Mumbai for ESR analysis. We also acknowledge SAIF, CDRI Lucknow for micro analysis and FAB-mass spectra. Thanks are also due to the Head, Department of Chemistry and physics, Dr. Hari Singh Gour University, Sagar (M.P.) for Laboratory facilities.

\section{References}

1. Abdallah S.M., Zyed M.A. and Mohammed G.G., Arabian J. Chem., 2010, 3, 103-113.

2. Ourari A., Ourari K., Moumeni W. and Sibous L., Trans. Met. Chem., 2006, 31, 169175.

3. Chandra S. and Kumar R., Trans. Met. Chem., 2004, 29, 269-275. 
4. Shirodkar S.G., Mane P.S. and Chondhekar T.K., Indian J. Chem., 2001, 40A, 11141117.

5. Soliman A.A. and Mohamed G.G., Thermochim Acta, 2004, 421, 151-159.

6. Mahajan K., Fahmi N. and Singh R.V., Indian J. Chem., 2007, 46A, 1221-1225.

7. Mahajan K., Swami M. and Singh R.V., Russ. J. Coord. Chem., 2009, 35, 179-185.

8. Mohanan K., Kumari S. and Rijulal G., J. Rare Earths, 2008, 26, 16-21.

9. Garg R., Saini M.K., Fahmi N. and Singh R.V., Trans. Met. Chem., 2006, 31, 362-367.

10. Sharma K., Singh R., Fahmi N. and Singh R.V., Spectrochim. Acta part, 2010, 75A, 422-427.

11. Dubey R.K., Dubey U.K. and Mishra C.M., Indian J. Chem., 2008, 47A, 1208-1212.

12. Mishra A.P. and Soni M., Metal-Based Drug, 2008.

13. Nakamoto K., 'Infrared and Raman Spectra of Inorganic, Coordination Compounds', $5^{\text {th }}$ ed. John Wiley and Sons, Part A \& B, New York, 1998.

14. Mishra A.P., Mishra R.K. and Shrivastava S.P., J. Serb. Chem. Soc., 2009, 74, 523-535.

15. Raman N., Raja S. J., Joseph J. and Raja J. D., J. Chil. Chem. Soc., 2007, 52, 1138 1144 .

16. Garg B.S. and Kumar D.N., Spectrochim. Acta, 2003, 59A, 229-234.

17. Spinu C., Kriza A. and Spinu L., Acta Chim. Slov., 2001, 48, 257-264.

18. Lever A.B.P., Inorganic Electronic Spectroscopy, $2^{\text {nd }}$ ed. Elsevier, New York, 1984.

19. Chandra S., Jain D., Sharma A.K. and Sharma P.; Molecules 2009, 14, 174-190.

20. Neelakantan M.A., Marriappan S.S., Dharmaraja J., Jeyakumar T. and Muthukumaran K., Spectrochim. Acta, 2008, 71A, 628-635.

21. Dutta R.L. and Syamal A., 'Elements of Magneto Chemistry', $2^{\text {nd }}$ ed. Affiliated East West Press, New Delhi, 1993.

22. Mishra A.P. and Pandey L.R., Indian J. Chem., 2005, 44A, 94-97.

23. Wang Y.F., Liu J.F., Xian H.D. and Zhao G.L., Molecules 2009, 14, 2582-2593.

24. Mohamed G.G., Omar M.M. and Ibrahim A.A., Eur. J. Med. Chem., 2009, 44, 4801-4812.

25. Sujamol M.S., Athira C.J., Sindhu Y. and Mohanan K., Spectrochim. Acta, 2010, 75A, 106-112.

26. Mishra A.P. and Pandey L.R., Indian J. Chem., 2005, 44A, 1800-1805.

27. Makode J.T., Yaul A.R., Bhadange S.G. and Aswar A.S., Russ. J. Inorg. Chem., 2009, 54, 1372-1377. 


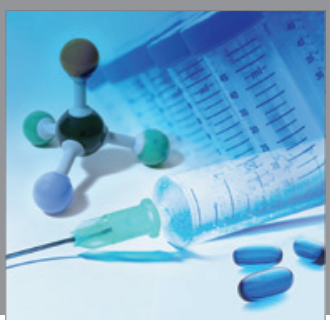

International Journal of

Medicinal Chemistry

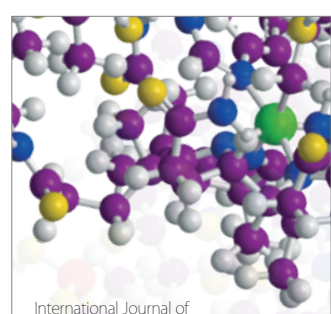

Carbohydrate Chemistry

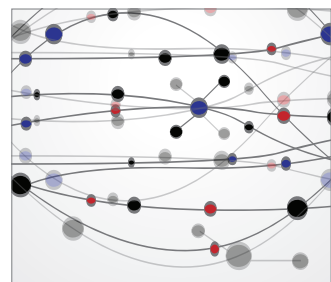

The Scientific World Journal
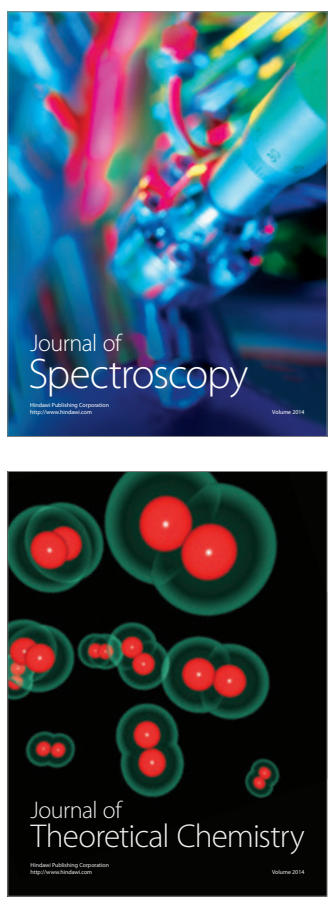
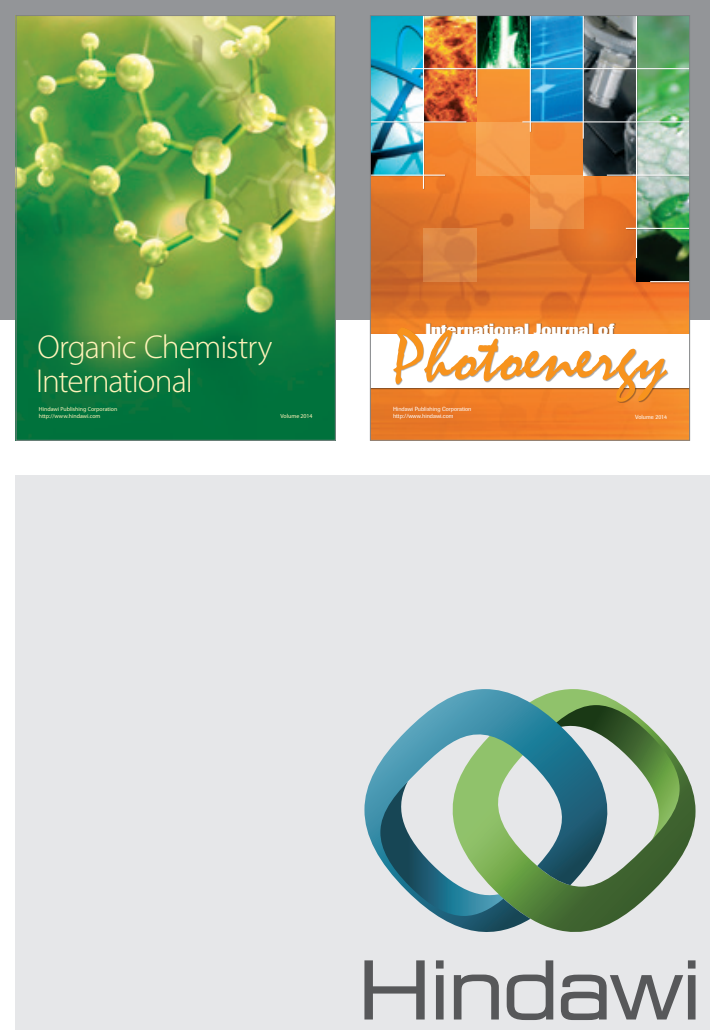

Submit your manuscripts at

http://www.hindawi.com
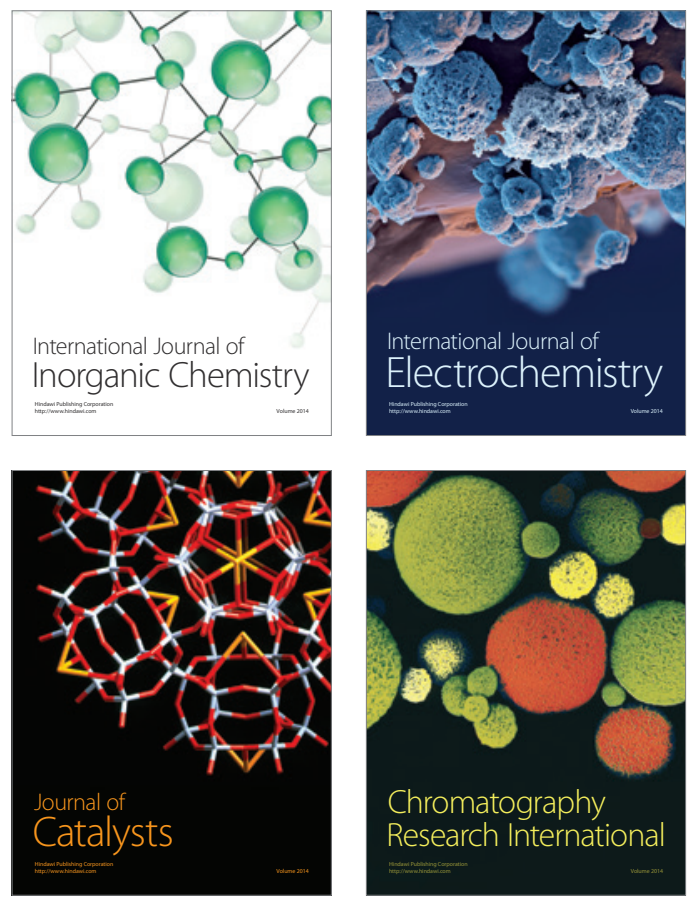
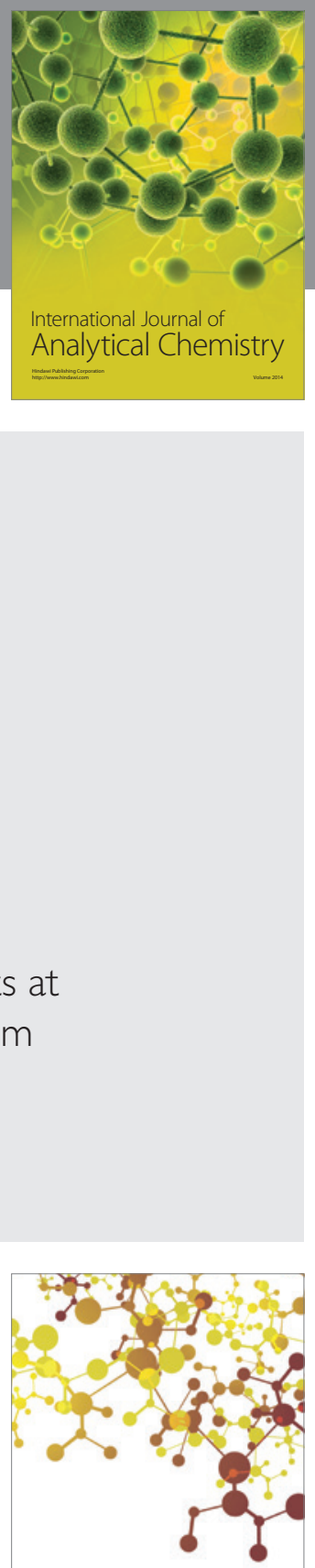

Journal of

Applied Chemistry
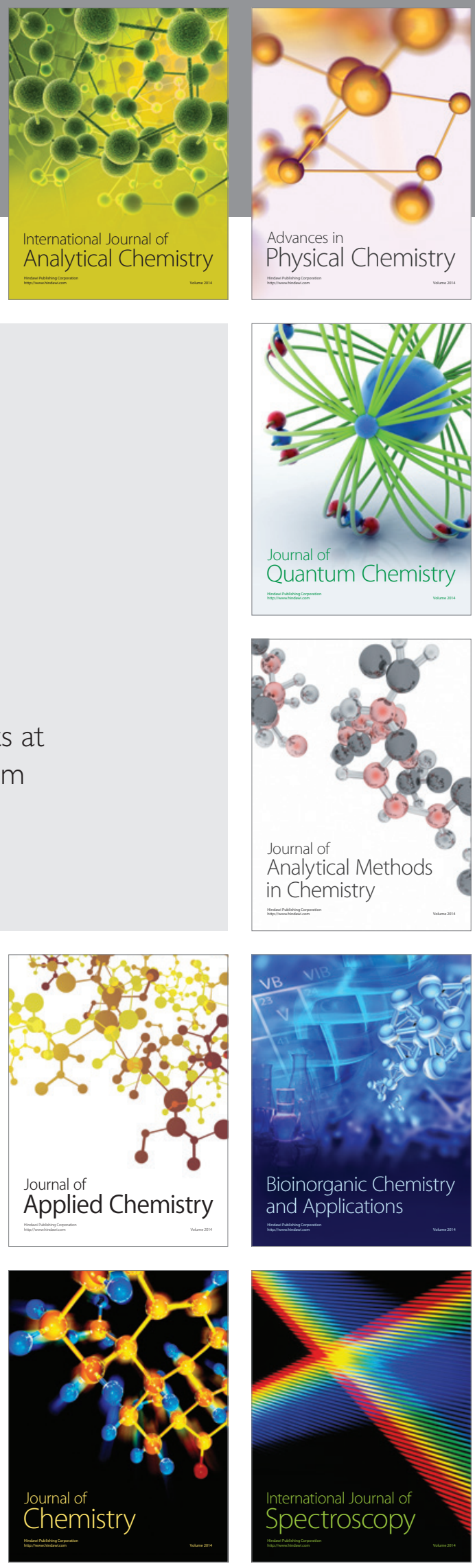